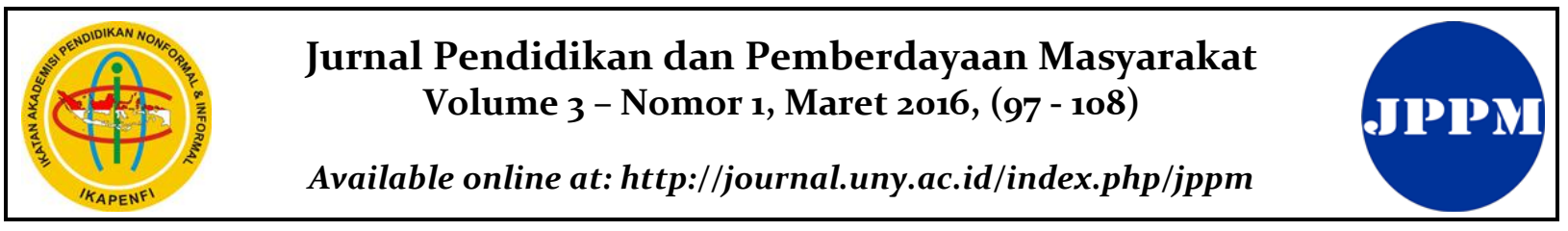

\title{
PARTISIPASI MASYARAKAT DALAM PENYELENGGARAAN PROGRAM-PROGRAM PUSAT KEGIATAN BELAJAR MASYARAKAT NGUDI KAPINTERAN
}

\author{
Yudan Hermawan $^{1)}$, Yoyon Suryono ${ }^{2)}$ \\ ${ }^{1}$ Pengembang Desa Wisata Bejiharjo, Karangmojo, Gunungkidul, Yogyakarta, Indonesia. \\ Email: yudanhermawan@gmail.com \\ ${ }^{2}$ Pendidikan Luar Sekolah, Program Pascasarjana, Universitas Negeri Yogyakarta. Jl. Colombo \\ No. 1, Karangmalang, Yogyakarta 55281, Indonesia. Email: yoyonsuryono@yahoo.com
}

\begin{abstract}
Abstrak
Tujuan penelitian untuk mengetahui: (1) tahapan, (2) bentuk, (3) faktor-faktor yang mempengaruhi, dan (4) strategi pengembangan partisipasi masyarakat dalam penyelenggaraan program-program PKBM Ngudi Kapinteran, Semanu, Gunungkidul. Penelitian kualitatif dengan metode studi kasus. Hasil penelitian yaitu (1) Tahapan partisipasi masyarakat dimulai dari proses perencanaan, pelaksanaan, evaluasi serta pemanfaatan hasil. (2) Bentuk partisipasi masyarakat terbagi dalam dua bentuk meliputi; (a) fisik yaitu material dan tenaga, dan (b) non fisik yaitu ide. (3) Faktor-faktor yang mempengaruhi partisipasi masyarakat yaitu faktor pendukung yang berupa budaya dan kebermanfaatan program sedangkan faktor penghambatnya adalah tingkat pendidikan dan jenis pekerjaan. (4) Strategi pengembangan partisipasi masyarakat yaitu dengan komunikasi, keterlibatan masyarakat dan pemberdayaan komunitas.
\end{abstract}

Kata Kunci: pemberdayaan, program, partisipasi masyarakat, PKBM

\section{COMMUNITY PARTICIPATION IN THE IMPLEMENTATION OF PROGRAMS OF COMMUNITY LEARNING CENTER (PKBM) NGUDI KAPINTERAN}

\begin{abstract}
The aim of research to determine: (1) the step, (2) forms, (3) affecting factors, and (4) development of community participation in implementing the programs of PKBM Ngudi Kapinteran, Semanu, Gunungkidul. The qualitative research with case study method. Results of the study are: (1) the steps of public participation are started from the process of plan, implementation, evaluation and utilization of results. (2) the form of community participation in divided into two forms, (a) physical wich are idea and thougt, and (b) the non-physical form of idea. (3) factors affecting public participation namely the supporting factors are of cultural and advantage of program and limiting factors are the level of education and type of work. (4) the development strategis are through communication, community involvement and community empowerment.
\end{abstract}

Keywords: empowerment, program, community participation, community learning center.

How to Cite: Hermawan, Y., \& Suryono, Y. (2016). Partisipasi masyarakat dalam penyelenggaraan program-program pusat kegiatan belajar masyarakat Ngudi Kapinteran. Jurnal Pendidikan dan $\begin{array}{lllll}\text { Pemberdayan } \quad \text { Masyarakat, } & \text { 3(1), } & \text { 97-108. } & \text { Retrieved }\end{array}$ http://journal.uny.ac.id/index.php/jppm/article/view/8111 


\section{Jurnal Pendidikan dan Pemberdayaan Masyarakat, 3 (1), Maret 2016 - 98}

Yudan Hermawan, Yoyon Suryono

\section{PENDAHULUAN}

Pemberdayaan masyarakat sudah berjalan kearah bagaimana masyarakat menentukan sendiri kebutuhannya sesuai dengan identifikasi masalah yang dihadapi. Artinya masyarakat mampu menggali permasalahan, mengidentifikasi, merencanakan sekaligus mencari pemecahan masalah karena mereka tahu persis apa yang mereka butuhkan dan harapkan. Kualitas sumber daya manusia (SDM) menjadi syarat utama untuk melaksanakan pembangunan, setiap manusia dituntut kompetensi individunya. Realitas perkembangan jaman yang semakin maju, membawa sejumlah implikasi bagi pengembangan SDM di Indonesia. Daya saing akan terwujud bila didukung oleh SDM yang berkualitas.

Pendidikan sebagai salah satu bagian dalam upaya pembangunan nasional memiliki kedudukan strategis untuk pengembangan sumber daya manusia. Dalam pendekatan sumber daya manusia, tujuan-tujuan dari pembangunan adalah optimalisasi dan membentuk manusia yang seutuhnya dalam aktivitas yang lebih produktif dan pengembangan sepenuh mungkin pengetahuan (knowledge), sikap (uptitude), dan keterampilan (skill), dari setiap kekuatan yang berhubungan dengan aktivitasnya setiap individu masing-masing. Pendidikan dianggap sebagai mekanisme kelembagaan pokok dalam mengembangkan keahlian dan pengetahuan. Pembangunan membutuhkan kualitas SDM yang unggul baik dalam kapasitas penguasaan ilmu pengetahuan dan teknologi maupun sikap mental, sehingga dapat menjadi subjek atau pelaku pembangunan yang handal. Oleh karena itu dimensi daya saing dalam SDM semakin menjadi faktor penting sehingga upaya memacu kualitas SDM berkualitas, yang berpendidikan, memiliki pengetahuan, keahlian dan keterampilan, serta sikap dan perilaku kerja melalui pendidikan merupakan tuntutan yang harus menjadi perhatian khusus.

Kualitas pendidikan merupakan salah satu indikator tingkat kesejahteraan masyarakat pada suatu Negara, sehingga semua negara berusaha untuk meningkatkan kualitas pendidikannya. Melalui pendidikan yang berkualitas akan menghasilkan sumber daya manusia yang lebih berkualitas yang mampu mengelola sumber daya alam secara efektif dan efisien. Dimilikinya sumber daya manusia yang berkualitas, produtivitas masyarakat akan meningkat, dan pada akhirnya diharapkan akan mampu meningkatkan daya saing dan kesejahteraan masyarakat.

Peningkatan mutu pendidikan yang selama ini dilakukan belum maksimal dan belum mampu memecahkan masalah dasar pendidikan artiya pendidikan dituntut untuk terus senantiasa mengikuti perubahan atau kebutuhan masyarakat. Pendidikan seharusnya merupakan jawaban dari permasalahan yang ada, namun ternyata mutu pendidikan di Indonesia belum maksimal untuk mengatasi hal tersebut. Selain itu yang menjadi permasalahan adalah belum optimalnya partisipasi masyarakat dalam keikutsertaan mengembangkan mutu pendidikan di Indonesia.

Pendidikan merupakan tanggung jawab bersama antara pemerintah dan masyarakat langsung, tanpa danya dukungan masyarakat pendidikan tidak akan berhasil secara optimal sesuai apa yang diharapkan. Undang-undang No.20 Tahun 2003 tentang sistem Pendidikan Nasional disebutkan bahwa peran serta yang dapat dilakukan oleh masyarakat dalam penyelenggaraan pendidikan, diatur pasal 54 ayat 1, peran serta masyarakat dalam pendidikan meliputi peran serta perseorangan, kelompok, keluarga, organisasi profesi, pengusaha dan organisasi kemasyarakatan dalam penyelenggaraan dan pengendalian mutu pelayanan mutu pelayanan pendidikan. Selanjutnya tertera pada pasal 2 menyebutkan bahwa masyarakat dapat berperan serta sebagai sumber, pelaksana dan pengguna hasil pendidikan. Ditegaskan lagi pada pasal 8 dan 9 masyarakat berhak untuk berperan serta dalam perencanaan, pelaksanaan, pengawasan dan evaluasi program pendidikan yang merupakan hak dan kewajiban bagi masyarakat di dalam proses pendidikan. Ini menggambarkan bahwa masyarakat yang menjadi pelaku utama dalam pengembangan pendidikan, kebijakan yang di buat dari pemerintah pusat sering tidak bisa di aplikasikan ke semua daerah 


\section{Jurnal Pendidikan dan Pemberdayaan Masyarakat, 3 (1), Maret 2016 - 99}

Yudan Hermawan, Yoyon Suryono

karena kurang mempertimbangkan keragaman dan kekhasan daerah.

Undang-Undang nomor 20 tahun 2003 tentang Sistem Pendidikan Nasional pasal 13 ayat 1 mengatakan bahwa jalur pendidikan terdiri atas pendidikan formal, non-formal, dan informal yang saling melengkapi dan memperkaya. Pada pasal 26 ayat (2) disebutkan bahwa "pendidikan nonformal berfungsi untuk mengembangkan potensi peserta didik dengan penekanan pada penguasaan pengetahuan dan keterampilan fungsional serta pengembangan sikap dan kepribadian profesional".

Definisi pendidikan luar sekolah telah banyak dikemukakan oleh para ahli, Coombs \& Ahmed (1974, p.8) menjelaskan bahwa pendidikan nonformal adalah setiap kegiatan pendidikan yang terorganisir dan sistematis yang diadakan diluar kerangka sistem pendidikan formal guna memberikan materi pembelajaran khusus bagi sebagian kelompok masyarakat, baik orang dewasa maupun anak-anak. Sejalan dengan hasil penelitian Ololube \& Egbezor (2012, p.8) mengungkapkan hubungan positif antara pendidikan nonformal dan pengurangan kemiskinan. Dalam istilah praktis, pendidikan nonformal membekali peserta dengan keterampilan yang mampu meningkatkan pendapatan dan meningkatkan kemandirian. Pendidikan luar sekolah menjadi suatu upaya untuk memberikan pelayanan pendidikan yang menyatu atas potensi masyarakat. Abdulhak \& Suprayogi (2012, p.23) yang menyatakan bahwa "Pendidikan nonformal adalah pendidikan yang kepemilikanya terfokus pada masyarakat, yang menyangkut pendirian, pendanaan, penggelolaan, dan aspek-aspek lainya, yang kegiatan dari, oleh dan untuk masyarakat" sehingga dapat di maknai pendidikan nonformal menekankan pada peran serta masyarakat dalam pendidikan.

Pusat Kegiatan Belajar Masyarakat merupakan satuan lembaga pendidikan nonformal, dimana PKBM sebagai tempat pembelajaran dan sumber informasi yang dibentuk dan dikelola oleh masyarakat yang berorientasi pada pemberdayaan potensi setempat untuk meningkatkan pengetahuan, keterampilan dan sikap masyarakat dalam bidang ekonomi, sosial dan budaya. Suryono (2014, p.12) memberikan definisi "PKBM memiliki potensi untuk menyelenggarakan seluruh layanan program pendidikan luar sekolah yang mencakup kegiatan-kegiatan nonformal dan informal".

PKBM tumbuh dan berkembang dari, oleh dan untuk masyarakat. Pendapat Yoo \& Cang (2012, p.369) PKBM merupakan lembaga lokal keaksaraan fungsional dan penyedia layanan sosial di luar sistem formal untuk mereka yang kurang beruntung di daerah pedesaan dan terpinggirkan, diatur dan dike-lola oleh masyarakat setempat. Pengertian tersebut bermakna bahwa PKBM berdiri di tengah masyarakat dengan mengembangkan potensi lokal. Sehingga keterlibatan masyarakat dalam pengembangan PKBM sangat diperlukan karena ukuran kemajuan suatu pusat kegiatan belajar masyarakat adalah partisipasi masyarakat dalam perencanaan, pendirian, penyelenggaraan maupun pengembangan PKBM.

Nasdian (2014, p.57) mengemukakan bahwa Partisipasi dalam pengembangan komunitas harus menciptakan peran serta yang maksimal dengan tujuan agar semua orang dalam masyarakat tersebut dapat dilibatkan secara aktif pada proses dan kegiatan masyarakat. Oleh karena itu dalam pengembangan masyarakat melalui PKBM haruslah mengotimalkan peran aktif dari masyarakat itu sendiri, dengan tujuan agar semua warga ikut terlibat dalam setiap prosesnya mulai dari pengambilan keputusan pada tahap perencanaan dan pelaksanaan juga dalam tahap implementasi serta evaluasi.

Hasil kajian literatur dan studi dokumentasi mengenai PKBM, diperoleh data bahwa awal PKBM dirintis pada pertengahan tahun 1998. Pada awal tahun 1999 PKBM di Indonesia telah tercatat sejumlah 815 buah. Selanjutnya pada akhir Maret 2000 semakin berkembang jumlahnya menjadi 1.643 buah, bahkan pada tahun 2005 tercatat 3.064 buah, perkembangan jaman turut serta mempengaruhi perkembangan PKBM hingga tahun 2010 terus meningkat jumlahnya menjadi 5.0oo buah, dan hingga akhir tahun 2012 tercatat ada 9.665 buah PKBM dimana hampir di setiap propinsi terdapat PKBM. Dilihat dari data tersebut PKBM di Indonesia semakin berkembang pesat. 


\section{Jurnal Pendidikan dan Pemberdayaan Masyarakat, 3 (1), Maret 2016 - 100 \\ Yudan Hermawan, Yoyon Suryono}

Gunungkidul merupakan salah satu kabupaten dari Daerah Istimewa Yogyakarta, sampai saat ini tercatat 44 PKBM yang tersebar di seluruh kecamatan. Dari sekian banyak PKBM terdapat beberapa yang terhambat untuk berkembang karena masih rendahnya partisipasi masyarakat untuk terlibat langsung dalam pengembangan PKBM, disi lain PKBM Ngudi Kapinteran yang merupakan tempat penyelenggaraan kegiatan pendidikan masyarakat di Kecamatan Semanu Kabupaten Gunungkidul Yogyakarta menunjukan keberhasilannya dalam mengotimalkan potensi sumberdaya manusia/masyarakat dan potensi lokal. PKBM tersebut terletak di daerah pedesaan yang mayoritas penduduknya adalah petani dan mempunyai latar pendidikan yang masih rendah.

Berdasarkan observasi, peneliti menemukan fakta-fakta yang dapat memberikan gambaran tentang lembaga PKBM Ngudi Kapiteran secara umum, sejak awal berdiri pada tanggal 15 Maret 2001 hingga sekarang terus mengalami perkembangan, dengan banyaknya program-program pemberdayaan masyarakat mulai dari pendidikan keaksaraan, pendidikan kesetaraan, pendidikan anak usia dini, pendidikan kecakapan hidup, pendidikan pemberdayaan perempuan, pendidikan kepemudaan, dan taman bacaan masyarakat. Beberapa prestasi telah diraih, terbukti pada tahun 2008 telah mendapatkan akreditasi untuk program kejar paket B, 2009 untuk program kejar paket A serta tahun 2010 untuk akreditasi program paket C, pada tahun 2008 PKBM Ngudi Kapinteran juga mendapatkan predikat sebagai PKBM Pembina dari Pusat Pengembangan Pendidikan Nonformal dan Informal region II, serta pada tahun 2009 mendapatkan juara II lomba penyelenggaran pendidikan kesetaraan tingat nasional untuk kategori sistem pembelajaran masih banyak lagi prestasi yang menjadikan PKBM Ngudi Kapinteran di akui oleh banyak kalangan khusunya kebermanfaatan oleh masyarakat sekitar. Prestasi yang diraih merupakan wujud nyata pelibatan masyarakat untuk terus aktif berpartisipasi dalam proses pengembangan PKBM Ngudi Kapinteran, sehingga penulis tertarik untuk meneliti dan mengkaji lebih dalam permasalahan tersebut dengan melakukan penelitian yang berjudul "Partisipasi $\mathrm{m}$ asyarakat dalam penyelenggaraan programprogram pusat kegiatan belajar masyarakat Ngudi Kapinteran Semanu Gunungkidul”.

\section{METODE}

\section{Tujuan Penelitian}

Penelitian ini bertujuan untuk mendapatkan gambaran yang mendalam tentang partisipasi masyarakat dalam penyelenggaraan program-program pusat kegiatan belajar masyarakat Ngudi Kapinteran Semanu Gunungkidul.

\section{Jenis Penelitian}

Penelitian kualitatif dengan metode studi kasus. Emzir (2010) menyampaikan jika studi kasus merupakan suatu penelitian kualitatif yang berusaha menemukan makna, menyelidiki proses, dan memperoleh pengertian dan pemahaman yang mendalam dari individu, kelompok dan situasi. Penelitian ini termasuk studi kasus tunggal terjalin, yakni kasus yang diteliti dalam penelitian ini adalah partisipasi masyarakat dalam penyelenggaraan program-program PKBM. Adapun rincian unit analisisnya adalah tahapan partisipasi, bentuk partisipasi, faktor pendukung dan faktor penghambat, dan strategi pengembangan partisipasi masyarakat dalam penyeenggaraan programprogram PKBM Ngudi Kapinteran. Penelitian ini dilaksanakan pada PKBM Ngudi Kapinteran secara purposive sampling dan mendapatkan penggelola PKBM, warga belajar, dan masyarakat desa Semanu.

\section{Waktu dan Tempat Penelitian}

Lokasi penelitian terletak di Desa Semanu, Kecamatan Semanu, Kabupaten Gunungkidul, Yogyakarta. Penelitian ini dilaksanakan selama empat bulan, terhitung mulai bulan Februari sampai Mei 2015.

\section{Data, Instrumen, dan Teknik Pengumpulan Data}

Sumber data yaitu penggelola PKBM, warga belajar dan masyarakat Semanu. Teknik pengumpulan data dilakukan dengan observasi partisipasi, wawancara mendalam, dan dokumentasi terhadap kelengkapan 


\section{Jurnal Pendidikan dan Pemberdayaan Masyarakat, 3 (1), Maret 2016 - 101}

Yudan Hermawan, Yoyon Suryono

arsip atau dokumen lembaga. Instrumen pengumpul data berasal dari peneliti sendiri bertindak sebagai instrument kunci yang dapat mengembangkan instrumen pedoman observasi, dokumentasi dan wawancara.

\section{Keabsahan Data}

Teknik yang digunakan untuk melacak atau membuktikan kebenaran data tersebut peneliti menggunakan teknik ketekunan pengamatan lapangan dan triangulasi. Ketekunan pengamatan dengan memperpanjang pengamatan dan teknik triangulasi dengan triangulasi teknik berfungsi sebagai pemeriksaan keabsahan data yang memanfaatkan sesuatu yang lain di luar data itu untuk keperluan pengecekan atau sebagai pembanding terhadap data tersebut (Moleong, 2010). Triangulasi sumber dengan mengecek keabsahan data dari sumber penggelola PKBM, warga belajar, masyarakat sedangkan triangulasi metode berasal dari metode wawancara, observasi, dan dokumentasi.

\section{Analisis Data}

Analisis data menggunakan teknik analisis model interaktif dari Milles \& Huberman (1994) yang terdiri dari reduksi data, penyajian data, dan penarikan kesimpulan.

\section{Reduksi Data}

Reduksi data dimaksudkan sebagai bentuk analisis yang mempertajam, memilih, memfokuskan, membuang, dan menyusun data dalam suatu cara dimana kesimpulan akhir dapat digambarkan dan diferifikasi (Emzir, 2010). Data tentang partisipasi masyarakat dalam pendidikan karakter yang diperoleh dari berbagai sumber dan metode sangat memungkinkan untuk mendapatkan data yang banyak dan belum relevan. Perlu dilakukan reduksi data dengan cara abstraksi membuat rangkuman yang inti, proses dan pernyataan yang perlu dijaga sehingga tetap berada dalam data penelitian

Data Display

Penyajian data dimaksudkan untuk menemukan pola-pola yang bermakna serta memberikan kemungkinan adanya penarikan kesimpulan. Penelitian ini yang terdapat beberapa fokus penelitian selanjutnya dihubungkan atau dikaitkan untuk menemukan maknanya, kemudian disusun secara sistematis, dari bentuk informasi yang kompleks diseleksi menjadi informasi yang sederhana.

Penarikan Kesimpulan

Pada bagian ini peneliti mengutarakan kesimpulannya dari data yang diperoleh. Penarikan kesimpulan dapat dilakukan dengan cara membandingkan kesesuaian antara pernyataan dari subjek penelitian dengan makna yang terkandung dalam konsep dasar penelitian tersebut.

\section{HASIL DAN PEMBAHASAN}

\section{Hasil}

Pusat Kegiatan Belajar Masyarakat merupakan satuan pendidikan nonformal yang berfungsi sebagai tempat pembelajaran dan sumber informasi yang dibentuk dan dikelola oleh masyarakat yang berorientasi pada pemberdayaan potensi setempat untuk meningkatkan pengetahuan, keterampilan dan sikap masyarakat dalam bidang ekonomi, sosial dan budaya. PKBM Ngudi Kapinteran merupakan lembaga yang berdiri di tengahtengah masyarakat pedesaan yang di kelola dan dirancang oleh masyarakat itu sendiri, PKBM Ngudi Kapinteran berdiri pada tanggal 15 Maret 2001 di sebuah Padukuhan Nitikan Timur Desa Semanu.

Hasil peneitian dapat dikatakan bahwa pendidikan merupakan bagian yang tidak dapat di pisahkan dari pembangunan masyarakat, dengan bekal pendidikan tersebut masyarakat diharapkan mampu berperan aktif dalam pembangunan. Pendidikan merupakan hal penting dalam menciptakan sumber daya manusia yang berkualitas. Pendidikan nonformal berbasis masyarakat menjadi sangat penting bagi masyarakat Semanu, karena mampu memberikan bekal ilmu dan ketramilan bagi semua masyarakat tanpa harus masuk dalam pendidikan formal

Manfaat kehadirannya telah banyak dirasakan oleh masyarakat Semanu, dengan motto PKBM yaitu dari, oleh, dan untuk masyarakat maka masyarakat tidak lagi hanya mengikuti program-program pendidikan luar sekolah yang diselenggarakan 
oleh pemerintah melainkan juga masyarakat juga ikut serta dalam merencanakan, melaksanakan, mengambil manfaat, dan mengevaluasi yang sesuai dengan kebutuhan dan potensi yang terdapat di lingkungannya, sehingga masyarakatpun bertanggung jawab terhadap kegiatan PKBM tersebut.

Keberhasilan PKBM Ngudi Kapinteran dalam memanajemen program-programnya tidak terlepas dari Penguatan pastisipasi masyarakat. Peran serta masyarakat dimaknai sebagai hak masyarakat untuk ikut mengontrol agenda dan urutan prioritas program untuk dirinya atau kelompoknya. Hasil penelitian Samah \& Aref (2009, p.45) menyatakan bahwa partisipasi merupakan proses pembangunan sosial, dimana orang sebagai subjek dalam lingkungan mereka sendiri, mencari cara untuk memenuhi kebutuhan kolektif mereka dan harapan untuk mengatasi masalah umum yang mereka hadapi

Tahapan Partisipasi Masyarakat dalam Penyelenggaraan Program-Program PKBM Ngudi Kapinteran

Tahapan partisipasi masyarakat dibagi menjadi 4 yaitu partisipasi masyarakat dalam perencanaan, pelaksanaan, evaluasi dan pengambilan manfaat.

\section{Partisipasi Masyarakat dalam Perencanaan}

Hasil penelitian di lapangan menunjukkan bahwa PKBM Ngudi Kapinteran selalu melibatkan masyarakat dalam pengambilan keputusan. Masyarakat dilibatkan setiap kali penentuan program-program yang akan dilaksnakan. Sebelum perencanaan pihak penggelola melakukan analisis kebutuhan terlebih dahulu yang akhirnya akan menjadi pedoman untuk merencanakan program. Wujud partisipasi masyarakat dalam pengambilan keputusan ini bermacam-macam, seperti kehadiran rapat, diskusi, sumbangan pikiran, tanggapan atau penolakan terhadap program yang ditawarkan.

Perencanaan program menjadi faktor utama dalam menentukan keberhasilan program PKBM. Keterlibatan masyarakat manjadi hal yang penting di PKBM Ngudi Kapinteran dalam proses perencanaan program dalam rangka menjaring, menyerap dan mendapatkan aspirasi, sehingga tercipta rasa memiliki terhadap program yang dilaksanakan. Masyarakat hadir dalam pertemuan tersebut untuk memberikan dukungan dan masukan dalam proses perencanaan program PKBM, setelah proses identifikasi selesai. Tokoh masyarakat baik formal maupun nonformal juga turut hadir dan berpartisipasi dalam memberikan masukan-masukan, sehingga dengan banyaknya usulan akan berdampak pada hasil perencanaan yang matang.

\section{Partisipasi dalam Pelaksanaan}

Hasil penelitian keterlibatan masyarakat dalam pelaksanaan yaitu dengan mempersiapkan segala sesuatu sebelum program dimulai, keterlibatan masyarakat dalam mempersiapkan sarana prasarana jelas terlihat, dengan suka rela membawa alat dan perlengkapan yang meraka punya untuk digunakan dalam proses pelatihan guna mencapai tujuan pembelajaran dan pengelola tidak harus menyewa. Tempat yang digunakan masyarakat dalam proses pembelajaran juga tidak harus terpaku pada kantor akan tetapi di tempat dimana warga tersebut menyepakatinya bisa di rumah warga belajar, balai desa maupun sekolah atas izin yang telah diberikan dari Kepala Desa setempat lebih lanjut partisipasi masyarakat dalam mempersiapkan sarana prasarana sangat diperlukan, mereka dengan suka rela membawa alat dan perlengkapan yang mereka punya untuk menunjang proses pembelajaran

\section{Partisipasi dalam Evaluasi}

Partisipasi masyarakat dalam evaluasi program-program PKBM merupakan aktivitas yang melibatkan pihak bersangkutan untuk mencari informasi dalam mengembangkan kegiatan atau program yang sedang berjalan, pencarian informasi agar berjalan sesuai waktu dan sasaran yang ditetapkan dilanjutkan dengan penilaian aspek efisiensi dan relevansi program, termasuk dampaknya terhadap konteks pencapaian tujuan baik positif maupun negatif.

Keberhasilan suatu program di PKBM Ngudi Kapinteran dapat dilihat dari kesesuaian antara perencanaan dan pelaksanaannya, terukur atau akuntabel hasilnya, serta 


\section{Jurnal Pendidikan dan Pemberdayaan Masyarakat, 3 (1), Maret 2016 - 103}

Yudan Hermawan, Yoyon Suryono

ada keberlanjutan aktivitas yang merupakan dampak dari program dengan pemanfaatan hasil itu sendiri. Melalui kegiatan monitoring dan evaluasi yang dilakukan olah PKBM Ngudi Kapinteran maka keberhasilan, dampak dan kendala pelaksanaan suatu program dapat diketahui.

Hasil temuan dari penelitian, evaluasi yang dilakukan dalam proses berjalanya program apabila ditemukan masalah atau penyimpangan, maka secara langsung disampaikan untuk segera ditindak lanjuti. PKBM Ngudi Kapinteran juga mengadakan pertemuan setiap awal dan akhir program guna mendapatkan evaluasi terkait program yang di selenggarakan oleh PKBM dengan melibatkan masyarakat, selanjutnya jenis evaluasi yang dilakukan oleh PKBM Ngudi Kapinteran yaitu membuka lebar masukanmasukan yang membanngun tanpa menuggu program selesai

\section{Partisipasi dalam Pengambilan Manfaat}

Parameter untuk mengukur tingkat kemajuan suatu PKBM adalah manfaat bagi masyarakat, yang dimaksud dengan manfaat adalah PKBM Ngudi Kapinteran tersebut telah memberikan sumbangan yang berarti bagi peningkatan mutu kehidupan komunitas tersebut. Sumbangan ini berupa peningkatan pengetahuan anggota masyarakat, peningkatan keterampilan, perbaikan perila$\mathrm{ku}$, peningkatan pendapatan, penciptaan lapangan kerja, penciptaan keharmonisan. misalkan yang dirasakan KRN setelah mengikuti program memasak akhirnya bisa mengolah bahan dasar singkong menjadi keripik yang berdaya jual yang akhirnya mampu meningkatkan hasil ekonominya.

Hasil lain dari penelitian juga menjelaskan bahwa partisipasi mayarakat dalam pengambilan manfaat program-program PKBM Ngudi Kapinteran juga dirasakan oleh warga sekitar, misalkan pemerintah Desa bisa memesan makanan snack dari warga belajar pelatihan, hal tersebut membuktikan bahwa masyarakat yang secara tidak langsung ikut dalam pelatihan juga merasakan dampak atau manfaat dari adanya program tersebut.
Bentuk Partisipasi Masyarakat dalam Penyelenggaraan Program-Program PKBM Ngudi Kapinteran

\section{Partisipasi dalam Bentuk Fisik}

Hasil penelitian di lapangan adalah partisipasi masyarakat dalam bentuk material, yaitu sumbangan sukarela dari masyarakat untuk mendukung program yang dilaksanakan PKBM, misalkan masyarakat membawa alat-alat individu yang mereka miliki untuk digunakan selama pelatihan tanpa meminta uang sewa dari penggelola, ada juga yang membawa bahan dasar dan masih banyak yang lain, selanjutnya partisipasi bentuk fisik berupa tenaga, yaitu dalam pelaksanaan program PKBM Ngudi Kapinteran terlihat dengan meluangkan waktu untuk mengikuti rapat/pertemuan dan kerja bakti, hal tersebut menjadi wujud dukungan bagi kemajuan PKBM. Bentuk partisipasi tenaga tunjukan untuk mempersiapkan sendiri segala keperluan pembelajaran sebelum pembelajaran dimulai. Hal lain yaitu gotong royong juga sering dilakukan oleh masyarakat dalam menjaga dan memperbaiki sarana dan prasaranan, misalkan dalam membuat tempat pendopo untuk pelatihan, membuat cakruk pintar untuk perpustakaan anak-anak.

\section{Partisipasi dalam Bentuk Non Fisik}

Hasil penelitian, diketahui bahwa masyarakat memberikan ide atau usulan terkait apa yang di inginkan untuk menjadi sebuah program, selain itu warga belajar juga memberikan evaluasi pada saat berjalannya progam agar ketika ada hal yang kurang pas dan kurang sesuai dengan tujuan, seperti yang di temukan dalam penelitian yaitu warga belajar PKBM Ngudi Kapinteran memberikan masukan dalam program pelatihan memasak untuk bisa dilanjutkan sampai proses pemasaran.

Faktor-faktor yang Mempengaruhi Partisipasi Masyarakat dalam Penyelenggaraan Program PKBM Ngudi Kapinteran

\section{Faktor Pendukung}

Faktor yang mempengaruhi partisipasi masyarakat dalam penyelenggaraan program PKBM yang di temukan di lapangan adalah 
Jurnal Pendidikan dan Pemberdayaan Masyarakat, 3 (1), Maret 2016 - 104

Yudan Hermawan, Yoyon Suryono

budaya, yaitu adanya sitem budaya gotongroyong yang melekat pada masyarakat di sana yang mampu memberikan semangat untuk bekerja secara bersama-sama dan hasilnya mampu dirasakan bersama. Kepedulian yang besar dari masyarakat yang satu dengan yang lain masih terlihat jelas, masyarakat desa yang masih menjunjung tinggi rasa kebersamaan sosial menjadi kekuatan masyarakat untuk berpartisipasi dalam program-program PKBM Ngudi Kapiteran. Faktor pendukung yang selanjatunya adalah kebermanfaatan program, jenis program mempunyai pengaruh terhadap partisipasi masyarakat dalam mengikuti program-program yang diselenggarakan oleh PKBM Ngudi Kapinteran, hal tersebut terbukti bahwa masyarakat akan antusias mengikuti program jika program tersebut dapat menambah ilmu dan ketrampilan guna menunjang usaha yang telah mereka geluti, sehingga akan mampu memberikan dampak positif dalam pengembangan usahanya.

\section{Faktor Penghambat}

Masyarakat yang mempunyai tingkat pendidikan yang rendah, maka mereka sulit untuk mengerti apa dan bagaimana pentingnya program yang dilaksanakan itu. Karena ketidaktahuan itulah kemudian timbul sikap yang acuh dan bermasa bodoh terhadap program PKBM, Masyarakat yang tingkat pendidikan rendah, kurang aktif dalam proses perencanaan mereka lebih semangat untuk berkontribusi dalam hal teknis seprti kerja bakti, persiapan program, pembuatan taman bacaan. Faktor penghambat yang lain yaitu jenis pekerjaan, hasil penelitian yaitu masyarakat Semanu merupakan masyarakat yang mayoritas adalah petani, mereka bisa berpartisipasi ketika bukan waktunya ke sawah. Pekerjaan yang lain yang di temukan dalam penelititian ini adalah pekerjaan buruh yang tidak bisa sama sekali di tinggalkan dan harus menunggu waktu libur yang akirnya berpengaruh pada partisipasi dari masyarakat itu sendiri.
Strategi Pengembangan Partisipasi Masyarakat dalam Penyelenggaraan Program PKBM Ngudi Kapinteran

\section{Komunikasi}

Penggelola PKBM Ngudi Kapinteran menggunakan komunikasi tersebut sebagai strategi pengembangan partisipasi masyarakat, komunikasi tersebut menjadi cara penggelola menyampaikan apa saja yang berkaitan dengan pelaksanaan program dengan harapan masyarakat akan secara aktif untuk bias berkontribusi dalam keberhasilan program-program PKBM.

Komunikasi yang dilakukan oleh PKBM Ngudi Kapinteran menjadi kegiatan yang efektif dalam menggerakan masyarakat untuk berpartisipasi, karena dalam komunikasi yang lakukan dengan musyawarah dijelaskan tentang manfaat serta kesempatan yang tersedia untuk menerima manfaat dari program-program PKBM

\section{Keterlibatan masyarakat}

Strategi pengembangan partisipasi masyarakat yang dilakukan PKBM ngudi kapinteran yaitu dengan pembuatan programprogram yang berdasarkan atas kebutuhan dan keinginan masyarakat yang akan di berdayakan atau masyarakat sasaran, hasil penelitian diketahui bahwa salah satu strategi yang di gunakan oleh PKBM Ngudi Kapintean dalam meningkatkan partisipasi masyarakat yaitu dengan melibatkan masyarakat dalam setiap proses, mulai dari perencanaan, pelaksanaan, evaluasi sampai pada pengambilan manfaat

\section{Pemberdayaan Komunitas}

Hasil penelitian PKBM Ngudi Kapinteran dalam meningkatkan partisipasi masyarakat yaitu dengan berbasis komunitas, yang dimaksudkan tidak hanya pada individu tetapi juga komunitas dan kelompokkelompok yang ada di dalam masyarakat Semanu, penggelola lebih mudah untuk mengoptimalkan setiap program dengan pembuatan atau pelibatan kelompok yang sudah ada di masyarakat, seperti kelompok pembuat sangkar burung mereka diajak untuk merancang kegiatan dan menjalankannya sendiri sehingga tingkat keterlibatan 
masyarakat khusunya pengrajin sangkar burung tinggi.Komunitas lain yang diberdayakan oleh PKBM Ngudi Kapinteran misalkan komunitas ibu-ibu PKK, Komunitas senam sehat dengan demikian PKBM sebagai agen pembangunan dan komunitas murni sebagai subjek dari program itu sendiri.

\section{Pembahasan}

Pusat Kegiatan Belajar Masyarakat merupakan satuan pendidikan nonformal yang berfungsi sebagai tempat pembelajaran dan sumber informasi yang dibentuk dan dikelola oleh masyarakat yang berorientasi pada pemberdayaan potensi setempat untuk meningkatkan pengetahuan, keterampilan dan sikap masyarakat dalam bidang ekonomi, sosial dan budaya. Sejalan yang di tulis UNESCO (2007, p.i) secara singkat mendefinisikan "Community Learning Centres (CLCs) have traditionally been regarded as useful venues in local commu-nities where literacy programmes and other non-formal education activities serving these communities take place". Artinya PKBM sebagai tempat yang sangar bermanfaat untuk masyarakat lokal di mana program keaksaraan dan kegiatan pendidikan nonformal lainnya yang melayani masyarakat mampu memberikan solusi atau memecahkan masalah hidupnya.

PKBM dibentuk oleh masyarakat, merupakan milik masyarakat, dan dikelola oleh masyarakat untuk memperluas pelayanan kebutuhan belajar masyarakat. Programprogram diarahkan untuk mengembangkan keterampilan dan pengetahuan yang tepat dan sesuai dengan kebutuhan dan peluang pasar dengan mempertimbangkan tersedianya potensi pendukung yang ada pada masyarakat itu sendiri, sehingga partisipasi masayarakat dalam PKBM akan sangat diperlukan.

Partisipasi menjadi faktor penting dalam keberhasilan PKBM, Onyenemezu (2012) pada hasil penelitiannya menunjukan bahwa keberhasilan setiap pengembangan masyarakat tergantung pada perencanaan, pelaksanaan, pemanfaatan dan keberlangsungan, oleh karena itu memerlukan integrasi dari berbagai unsur masyarakat. Tanpa adanya partisipasi PKBM tidak mungkin bisa berkembang. Pendpat tersebut sejalan dengan Dwiningrum (2011, p.50) mempunyai pandangan tentang partisipasi "Partisipasi merupakan keterlibatan mental dan emosi dari sesorang di dalam situasi kelompok yang mendorong mereka untuk menyokong kepada pencapaian tujuan pada tujuan kelompok tersebut dan ikut bertanggung jawab terhadap kelompoknya", dalam artian masyarakat tidak hanya ikut sebagai peserta dalam program PKBM akan tetapi juga bertanggungjawab dengan pengembangan PKBM.

Partisipasi dibagi menjadi dalam empat tahap pengabilan perencanaan, parrtisipasi dalam pelaksanaan kagiatan, partisipasi dalam pemantauan dan evaluasi, partisipasi dalam pengambilan manfaat (Mardikanto, 2013, p.82). Tahapan partisipasi masyarakat dalam penyelenggaraan program-program pusat kegiatan belajar masyarakat Ngudi Kapinteran Semanu Gunungkidul yaitu;

Pertama, partisipasi dalam perencanaan, masyarakat dilibatkan penuh dalam proses perencanaan program melalui musyawarah bersama, pada musayawarah tersebut ide dan usulan dari masyarakat menjadi hal penting atau acuan dalam perencanaan program, sejalan dengan pendapat Mardikanto (2013, p.236) bahwa adanya suatu perencanaan program/kegiatan pemberdayaan masyarakat akan memberikan kerangka kerja yang dapat dijadikan acuan oleh para fasilitator dan semua pemangku kepentingan termasuk warga belajar untuk mengambil keputusan tentang kegiatankegiatan yang seharusnya dilaksanakan demi terciptanya tujuan pembangunan yang diinginkan, perencanaan program menjadi langkah pertema sebelum program itu dilaksanakan Saffer (1999) menjelaskan bahwa mendiagnosis dan mendefinisikan masalah, mengumpulkan dan menganalisis informasi, mendefinisikan prioritas dan menetapkan tujuan menilai sumber daya yang tersedia, memutuskan dan perencanaan program, merancang strategi untuk melaksanakan program adalah tingkatan partisipasi dalam perencanaan program, sehingga dengan terlibatnya masyarakat dalam perencanaan program PKBM Ngudi Kapinteran, memberikan rumusan program yang sesuai kebutuh- 


\section{Jurnal Pendidikan dan Pemberdayaan Masyarakat, 3 (1), Maret 2016 - 106}

Yudan Hermawan, Yoyon Suryono

an masyarakat dan mampu memecahkan masalah dalam kehidupanya.

Kedua, partisipasi dalam pelaksanaan, pada proses pelaksanaan masyarakat ikut berpartisipasi sebelum program dimulai sampai pada akhir program, sesuai pendapat dari Mardikanto (2013) Partisipasi masyarakat dalam pelaksanaan harus di artikan sebagai pemerataan sumbangan masyarakat dalam bentuk tenaga kerja, uang tunai, dan atau beragam bentuk korban lainya yang sepadan dengan manfaat yang akan diterima oleh masing-masing warga masyarakat yang bersangkutan.

Ketiga, partisipasi dalam pengambilan manfaat, yaitu masyarakat berpartisipasi untuk bisa menggunakan keterampilan yang telah dimiliki dalam meningkatkan kualitas kehidupannya, Sumbangan ini dapat berupa peningkatan pengetahuan anggota masyarakat, peningkatan keterampilan, perbaikan perilaku, peningkatan pendapatan, penciptaan lapangan kerja, penciptaan keharmonisan dan lain-lain, Direktorat Jenderal Pendidikan Anak Usia Dini Nonformal dan Informal (2012, p.8). misalkan yang dirasakan salah satu peserta pelatihan setelah mengikuti program memasak PKBM Ngudi Kapinteran akhirnya bisa mengolah bahan dasar singkong menjadi keripik yang berdaya jual yang akhirnya mampu meningkatkan hasil ekonominya.

Keempat, partisipasi masyarakat dalam evaluasi program-program PKBM merupakan aktifitas yang melibatkan pihak bersangkutan untuk mencari informasi dalam mengembangkan kegiatan atau program yang sedang berjalan, pencarian informasi agar berjalan sesuai waktu dan sasaran yang ditetapkan dilanjutkan dengan penilaian aspek efisiensi dan relevansi program, termasuk dampaknya terhadap konteks pencapaian tujuan baik positif maupun negative, seperti yang dijelaskan oleh Yandav (Mardikanto, 2013) Partisipasi dalam pemantauan dan evaluasi sangatlah diperlukan, bukan saja bertujuan untuk mengetahui bagaimana keberhasilan pelaksanaan program berjalan tetapi juga diperlukan untuk memperoleh umpan balik tentang masalahmasalah dan kendala yang muncul dalam proses pelaksanaan, sejalan dengan itu hasil evaluasi yang dilakukan PKBM Ngudi Kapinteran menjadi informasi berharga yang dapat dijadikan pedoman bagi ketua lembaga PKBM untuk mengambil keputusan pengembangan organisasi yang dipimpinnya

Bentuk partisipasi masyarakat PKBM Ngudi Kapinteran dalam penyelenggaraan program-program yaitu fisik dan nonfisik, hal ini mendukung pendapat dari Uphoff (Nasution, 2009, p.43) bahwa partisipasi dalam pembangunan dapat dilakukan melalui keikutsertaan masyarakat dalam memberikan kontribusi guna menunjang pelaksanaan pembangunan yang berwujud tenaga, uang, barang, material ataupun ide-ide, informasi yang berguna untuk pelaksanaan pembangunan.

Pertama, bentuk fisik partisipasi masyarakat dalam penyelenggaran program PKBM Ngudi Kapinteran yaitu; Material, yaitu masyarakat dengan suka rela memberikan sumbangan sarana prasarana untuk keberhasilan program baik berupa tempat pembelajaran maupun alat pembelajaran dan tenaga, yaitu dengan semangat kebersamaan (gotong royong) masyarakat bekerja untuk keberhasilan program-program PKBM.

Kedua, bentuk nonfisik partisipasi masyarakat dalam penyelenggaran program PKBM Ngudi Kapinteran yaitu ide dan pikiran yang dilakukan oleh masyarakat, dirumuskan secara bersama dalam musyawarah.

Faktor-faktor yang mempengaruhi partisipasi masyarakat dalam penyelenggaraan program PKBM Ngudi Kapinteran Semanu, Gunungkidul terbagi dua yaitu; Pertama, faktor pendukung adalah budaya, budaya menjunjung tinggi rasa kebersamaan berpengaruh pada tingkat partisipasi dan selanjutnya yaitu kebermanfaatan program, masyarakat antusias mengikuti program PKBM apabila program tersebut menambah ilmu dan keterampilan. Kedua, faktor penghambat yaitu tingkat pendidikan, yang masih tergolong rendah mereka lebih cenderung susah untuk ikut berpartisipasi khususnya dalam proses penjaringan idea tau perencanaan karena keterbatasan pemahaman dan kemampuan, mereka lebih cenderung berpartisipasi dalam hal teknis, Slamet (1993, 
p.15) menyatakan tingkat pendidikan sangat berpengaruh dalam cara pandang pada setiap fenomena, faktor pendidikan terebut sangat mempengaruhi dalam berpartisipasi karena akan lebih mudah berkomunikasi dengan orang luar dan lebih cepat tanggap terhadap perkembangan. faktor selanjutnya adalah jenis pekerjaan menjadi kendala apabila program tidak bisa dilaksanakan disaat hari atau jam kerja sejalan dengan pendapat Slamet (1993, p.116) jenis pekerjaan masyarakat akan mempengaruhi dan menentukan tingkat partisipasi karena kaitannya dengan penghasilan dan terlebih pada waktu luang meraka untuk digunakan dalam berpartisipasi

Strategi pengembangan partisipasi masyarakat dalam penyelenggaran programberdayaan program PKBM Ngudi Kapinteran Semanu, Gunungkidul yaitu: Pertama, komunikasi, Partisipasi tercipta melalui komunikasi misalkan; sosialisasi program, musyawarah penentuan program, musyawarah evaluasi program dan lain-lain. Pesan disampaikan untuk memberikan informasi dan pemahaman terhadap masyarakat terkait program PKBM, Theresia, dkk (2014, p.212) memeberikan pendapat bahwa "komunikasi pembanguanan merupakan cara yang harus ditempuh untuk membangkitkan dan mengembangkan partisipasi masyarakat dalam proses pembangunanan",

Kedua, keterlibatan masyarakat, dengan melibatkan masyarakat mulai dari proses perencanaan, pelaksanaan, pengambilan manfaat dan evaluasi, hal tersebut menjadi salah satu cara yang efektif untuk menampung dan mengakomodasi berbagai kepentingan yang beragam dari masyarakat, Partisipasi dalam pengembangan komunitas harus menciptakan peran serta yang maksimal dengan tujuan agar semua orang dalam masyarakat tersebut dapat dilibatkan secara atif pada proses dan kegiatan masyarakat. Ketiga, pemberdayaan komunitas, misalkan komunitas pengrajin sangkar burung, ibu PKK, senam sehat, kelompok memasak. Masyarakat akan menyusun program, bekerja secara sistematis serta bisa merasakan adanya perkembangan dan kemajuan sebagai hasil kegiatan mereka, sehingga akan menumbuhkan motivasi untuk berpartisipasi dalam program PKBM Ngudi Kapinteran. Hal tersebut sejalan dengan hasil penelitian Jong-Hyo \& Hyeryung (2010, p.351) menyatakan bahwa belajar berorientasi kelompok merupakan faktor kunci dari masyarakat kurang mampu untuk bisa berpartisipasi belajar sepanjang hayat.

\section{SIMPULAN DAN SARAN}

\section{Simpulan}

Keberhasilan PKBM Ngudi Kapinteran terletak pada partisipasi masyarakat, Hasil penelitian ini adalah sebagai berikut. (1) Tahapan partisipasi masyarakat dalam penyelenggaraan program-program PKBM Ngudi Kapinteran Semanu, Gunungkidul dimulai dari proses pengambilan keputusan, pelaksanaan, evaluasi serta pemanfaatan hasil. (2) Bentuk partisipasi masyarakat PKBM Ngudi Kapinteran dalam penyelenggaraan program-program terbagi dalam dua bentuk fisik yaitu material dan tenaga dan non fisik yaitu ide. (3) Faktor-faktor yang mempengaruhi partisipasi masyarakat dalam penyelenggaraan program PKBM Ngudi Kapinteran Semanu, Gunungkidul yaitu faktor pendukung yang berupa budaya dan kebermanfaatan program sedangkan faktor penghambatnya adalah tingkat pendidikan dan jenis pekerjaan. (4) Strategi pengembangan partisipasi masyarakat dalam penyelenggaran program-program PKBM Ngudi Kapinteran, Semanu, Gunungkidul yaitu dengan komunikasi, keterlibatan masyarakat dan pemberdayaan komunitas

\section{Saran}

Adapun saranya: (1) PKBM merupakan lembaga yang berdiri dari untuk dan oleh masyarakat, keterlibatan masyarakat haruslah selalu menjadi prioritas utama dalam setiap kegiatan yang dilakukan PKBM, maka strategi-strategi dari penggelola dalam meningkatkan partisipasi masyarakat harus lebih ditekankan. PKBM harus melibatkan seluruh elemen masyarakat dalam setiap program yang dilaksanakan. Baik masyarakat yang tingkat pendidikanya tinggi ataupun yang relatife rendah, masyarakat tersebut menjadi subjek sesuai dengan kemampuan masing-masing. (2) Peneliti selanjutnya da- 


\section{Jurnal Pendidikan dan Pemberdayaan Masyarakat, 3 (1), Maret 2016 - 108 \\ Yudan Hermawan, Yoyon Suryono}

pat dilanjutkan pada model pengembangan partisipasi masyarakat dalam penyelenggaraan program-program PKBM mengingat pentingya partisipasi masyarakat dalam pengembangan PKBM.

\section{DAFTAR PUSTAKA}

Abdulhak, I \& Suprayogi, U. (2012). Penelitian tindakan dalam pendidikan nonformal. Jakarta: PT. Raja Grafindo Pustaka

Coombs, P. \& Ahmed, M. (1974). Attacking rural poverty. Baltimore: The John Hopkins University Press.

Emzir. (2010). Metodelogi penelitian kualitatif analisis data. Jakarta: Raja Grasindo.

Dwiningrum, S.I.A. (2011). Desentralisasi dan partisipasi masyarakat dalam pendidikan. Yogyakarta: Pustaka Pelajar.

Jong-Hyo, P. \& Hyeryung, J. (2010). A study to explore characteristics and determinant factors of participation in lifelong learning for the underprivileged. KEDI Journal of Educational.

Mardikanto, T. (2013). Pengembangan masyarakat. Surakarta: UNS Press

Mardikanto, T \& Soebianto, P. (2013). Pemberdayaan masyarakat, dalam perspektif kebijakan publik. Bandung: Alfabeta.

Milles, M.B. \& Huberman, A.M. (1994). Analisis data kualitatif. Jakarta: Universitas Indonesia Press.

Moleong, L.J. (2010). Metodologi penelitian kualitatif. Bandung: PT Remaja Rosdakarya.

Nasdian, T.F. (2014). Pengembangan masyarakat. Jakarta: Yayasan Pustaka Obor Indonesia.
Ololube, N.P \& Egbezor, D.E. (2012). A critical assessment of the role/ importance of nonformal education to human and national development in Nigeria: future trends. International journal of scientific research in education, June 2012, Vol. 5(2), 71-93. Retrived from http://www.ijsre.com/Vol.,\%205_2_Ololube\%2oE\% \% 2oEgbezor.pdf

Onyenemezu, C. E. (2014). The imperative of citizen's participation in community development. Academic research internasional. Retrived from http://www.savap.org.pk/journals/ARI $n t . /$ Vol.5(1)/2014(5.1-22).pdf

Republik Indonesia (2003). Undang-undang RI nomor 20 tahun 2003 tentang sistem pendidikan Nasional

Samah, A. A \& Aref, F. (2009). People's participation in community development: a case study village settlement in malaysia. World Rural Observations.

Slamet, Y. (1993). Pembangunan masyarakat berwawasan partisipasi. Surakarta: UNS Press.

Suryono, Y. (2014). Pusat kegiatan belajar masyarakat (PKBM). Yogyakarta: UNY Press.

Theresia, A. (2014). Pembangunan berbasis masyarakat. Bandung: Alfabeta.

UNESCO. (2007). Strengthening Community Learning Centres through Linkages and Networks: A Synthesis of Six Country Reports. Bangkok: UNESCO.

Yoo, S. \& Cang, E.D. (2012). Popular education for people's empowerment in the community learning center (CLC) project in Bangladesh. KEDI journal of educational policy 